\title{
The utility of diffusion-weighted imaging in differentiation of papillary and clear cell subtypes of renal cell carcinoma
}

\section{Renal Hücreli Kanserde Difüzyon Ağırlıklı MR Görüntüleme Kullanılarak Papiller ve Şeffaf Hücreli Subtiplerin Ayırt Edilmesi}

\author{
Hale Çolakoğlu Er ${ }^{1}$, Elif Peker ${ }^{2}$, Ayşe Erden ${ }^{2}$, Erdem Öztürk $^{3}$ \\ ${ }^{1}$ Şehitkamil Devlet Hastanesi, Radyoloji Bölümü, Gaziantep, Turkey \\ ${ }^{2}$ Ankara Üniversitesi Tıp Fakültesi, Radyoloji Ana Bilim Dalı, Ankara, Turkey \\ ${ }^{3}$ Ankara Üniversitesi Tıp Fakültesi, Üroloji Ana Bilim Dalı, Ankara,Turkey
}

\section{ÖZET}

Amaç: Bu çalışmadaki amacımız, papiller tip ile şeffaf hücreli renal hücreli kanser alt tiplerini ayırt etmede difüzyon ağırlıklı görüntülemenin yararlılı̆gını belirlemektir.

Yöntem: Papiller tip ve şeffaf hücreli tip renal kanseri olan toplam 16 olgu retrospektif olarak değerlenmiştir. İnceleme 3 Tesla alan gücüne sahip manyetik rezonans cihazında gerçekleştirilmiştir. Renal kitle konturları T2 ağırlıklı görüntülerden de faydalanılarak sınırlanmış ve kistik-nekrotik dejenerasyon alanları dışarıda kalacak şekilde elle çizilen ilgi alanı (freehand ROI) kullanılarak kitlelerin solid komponentlerinin $b=50 \mathrm{sn} / \mathrm{mm}^{2}$ ve $b=1000 \mathrm{sn} / \mathrm{mm}^{2}$ DAG'lerde görünür difüzyon katsayı (apparent diffusion coefficient $=$ ADC) değerleri ve ortalama sinyal intensite (SI) değerleri ile böbreğin normal parankiminin ortalama sinyal intensite (SI) değerleri ölçülmüştür. Normal parankimin sinyal intensite değerlerinin ölçümü için ROI kortikomedüller bileşkeye yerleştirilmiştir.

Bulgular: Ortalama ADC değeri papiller RHK' larda $\left(0.991 \pm 0.143 \times 10^{-3} \mathrm{~mm}^{2} / \mathrm{sn}\right)$ şeffaf hücreli RHK'lardan istatistiksel olarak anlamlı derecede düşüktü $\left(1.296 \pm .0 .277 \times 10^{-3} \mathrm{~mm}^{2} / \mathrm{sn}\right)(\mathrm{p}<0.05)$. Ayrıca papiller RHK grubunda, $b=1000 \mathrm{sn} / \mathrm{mm}^{2}$ DAG'lerde ölçülen ortalama SI değerleri $(22.8 \pm 6.3)$, normal parankimden $(43.4 \pm 14.8)$; şeffaf hücreli RHK grubunda $b=50$ $\mathrm{sn} / \mathrm{mm}^{2}$ DAG'lerde ölçülen ortalama SI değerleri (102 \pm 27.5$)$, normal parankimden (138.8 \pm 33 ) istatistiksel olarak farklıydı $(\mathrm{p}<0.05)$.

Sonuç: Papiller ve şeffaf hücreli kanser subtiplerinin ayırt edilebilmesinde difüzyon ağırlıklı görüntüleme faydalı bir yöntem olabilir. Papiller hücreli kanserlerin sınırları, $b=1000 \mathrm{sn} / \mathrm{mm} 2$; şeffaf hücreli kanserlerin sınırları ise $b=50 \mathrm{sn} / \mathrm{mm} 2$ DAG'lerde daha net olarak seçilebilmektedir. Bulgularımızın desteklenmesi için daha geniş hasta serisini kapsayan çalışmalara gereksinim vardir.

Anahtar Kelimeler: Renal hücreli kanser; magnetik rezonans görüntüleme; difüzyon ağılıklı görüntüleme; görünür difüzyon katsayısı.

\section{ABSTRACT}

Objectıve: To determine the utility of diffusion-weighted imaging (DWI) in differentiation of papillary and clear cell subtypes of renal cell carcinoma (RCC).

Methods: A total of 16 patients with papillary RCC and clear cell RCC were enrolled in this retrospective study. Patients underwent MRI with a 3.0-Tesla wholebody system (MAGNETOM Verio, Siemens, Erlangen, Germany) using a standard body matrix coil. Apparent diffusion coefficient (ADC) values and signal intensity (SI) values at b=50 s/mm2 b=1000 s/mm2 DWI of solid components of the renal masses and SI values of normal renal parenchyma were measured. A freehand ROI was drawn around the peripheral margin of the tumor on the diffusion images excluding the cystic or necrotic portions, while referring to the T2-weighted conventional images for verification of lesion boundaries. To measure SI values of normal renal parenchyma, ROIs were placed on the normal corticomedullary junction.

Results: Mean ADC value was statistically significantly lower in papillary RCC $\left(0.991 \pm 0.143 \times 10^{-3} \mathrm{~mm}^{2} / \mathrm{s}\right)$ than in that of clear cell RCC $\left(1.296 \pm .0 .277 \times 10^{-3} \mathrm{~mm}^{2} / \mathrm{s}\right)$. For the papillary RCC group, there was statistically significant difference $(\mathrm{p}<0.05)$ between mean SI values of normal parenchyma $(22.8 \pm 6.3)$ and lesion $(43.4 \pm 14.8)$ at $\mathrm{b}=1000 \mathrm{~s} / \mathrm{mm} 2 \mathrm{DWI}$; for the clear cell RCC group there was statistically significant difference $(\mathrm{p}<0.05)$ between mean SI value of normal parenchyma $(138.8 \pm 33)$ and lesion $(102 \pm 27.5)$ at $b=50 \mathrm{~s} / \mathrm{mm} 2 \mathrm{DWI}$

Conclusion: For discrimination of papillary and clear cell subtypes of RCC, DWI seems to be a useful method. The boundaries of papillary RCC can be more clearly perceived on $b=1000 \mathrm{~s} / \mathrm{mm} 2$ and that of clear cell RCC on $b=50 \mathrm{~s} / \mathrm{mm} 2$ DWI. However, more extensive research on a larger series of patients are needed to support our findings.

Key words: renal cell carcinoma, magnetic resonance imaging, diffusion weighted imaging, apparent diffusion coef

\section{Introduction}

The most common renal malignancy is renal cell carcinoma (RCC) originates from the renal parenchyma. The global incidence of RCC has increased over the past twenty years by $2 \%$ per year (1). The most common subtypes include 
clear cell RCC (70\% of RCC cases), papillary RCC (10-15\%), and chromophobe RCC (5\%) $(2,3)$.

Diffusion-weighted imaging (DWI) is a magnetic resonance imaging (MRI) technique based on the molecular mobility of water (4). On DWI, lesions with dense cellularity and poor interstitium that restrict the mobility of water molecules exhibit high signal intensity (5). The apparent diffusion coefficient (ADC) allows for quantification of diffusivity, which is shown to be restricted in the majority of malignancies due to higher cellularity compared to surrounding tissue. The measurable data obtained by DWI can give opinion about the nature of the lesions in various parts of the body and help to characterize them without using intravenous contrast medium (6).

Characterization of the renal tumors before operation is necessary for clinical decision and evaluation of prognosis (3). Recent studies on MRI of the renal tumors showed that ADC values obtained by DWI may provide a new quantitative data for differentiating benign tumors from the malignant ones and may help identifying pathologic subtypes of the neoplasms $(7,8)$. The aim of this study was to determine the utility of DWI in discrimination of papillary and clear cell subtypes of RCC.

\section{Materials and Methods}

\section{Patients}

A total of 29 patients with renal mass underwent dynamic renal MRI using 3.0 Tesla system in our radiology department between October 2012 and November 2014 were retrospectively analyzed. Thirteen patients were excluded for absence of histopathologic results. Sixteen patients (14 male, 2 female; age range, 37-75 years, mean 58 years) whose histopathological data were available were included to the study. Nine patients had clear cell RCC, 7 patients had papillary type RCC.

\section{MR techniques}

The patients underwent MRI at 3.0 Tesla whole-body system (Magnetom Verio, Siemens) using standard body matrix coil. The imager operates with a maximum gradient strength of $45 \mathrm{mT} / \mathrm{m}$ and a slew rate of 200 $\mathrm{mT} / \mathrm{m} / \mathrm{s}$ in all three directions. Conventional
MR images and DW images were acquired during the same procedure. The MR imaging examination consisted of coronal T2-weighted half-Fourier single-shot turbo spin-echo (HASTE) multi breathehold images, axial T2weighted turbo spin-echo (TSE) BLADE images, axial T2-weighted images with fat saturation, axial dual echo T1-weighted gradient-echo images, axial DW images, and axial 3D fat suppressed T1-weighted gradient echo (VIBE: Volume Interpolated Breathhold Examination) images. All pulse sequence parameters used in this study are listed in detail in Table 1.

After the acquisition of precontrast routine sequences for renal MR imaging, DW images with three different $b$ values $(50,400$, and $1000 \mathrm{~s} / \mathrm{mm} 2$ ) were obtained in the axial plane using a single-shot multi-slice echoplanar imaging (EPI) sequence with spectral adiabatic inversion recovery fat suppression and the following parameters: repetition time/echo time, 5500/75 ms; EPI factor, 122 ; field of view, $380 \times 296 \mathrm{~mm}$; matrix size, $128 \times 102$; slice thickness, $5.0 \mathrm{~mm}$; distance factor, 20\%; averages, 4; reduction factor, 2; and receiver bandwidth, $2442 \mathrm{~Hz} / \mathrm{Px}$. The acquisition time for the DWI was $4 \mathrm{~min}$ and 24 seconds.

\section{Image interpretation}

The ADC maps were automatically generated by using a monoexponential decay model including all three $b$-values at Siemens Software Version syngo MR B17. ADC values and signal intensity of normal renal parenchyma and solid components of the renal masses were determined as follows: Freehand (ROI)s covering the tumor was defined for the lesions detected on the diffusion images, while referring to the T2-weighted conventional sequence for verification of lesion boundaries. Diffusion-weighted images with $b=50 \mathrm{~s} / \mathrm{mm}^{2}$ was used for the mixed cystic and solid lesions and $b=1000 \mathrm{~s} / \mathrm{mm}^{2}$ DWI was selected for the evaluation of solid lesions. On each slice, the high signal intensity of tumor boundaries was traced manually_and ROIs were copied to the corresponding ADC map to measure ADC values. To measure SI values of normal renal parenchyma, ROIs were placed in the normal corticomedullary junction of the kidney. Signal intensities of normal kidney and papillary RCC were measured on $b=1000 \mathrm{~s} / \mathrm{mm}^{2}$ diffusion 
images. Signal intensities of normal kidney and clear cell RCC was measured on $b=50$ $\mathrm{s} / \mathrm{mm}^{2}$ diffusion images.

Table 1. Pulse sequence parameters

\begin{tabular}{|c|c|c|c|c|c|}
\hline & $\begin{array}{l}\text { T2-weighted } \\
\text { HASTE }\end{array}$ & $\begin{array}{l}\text { T2- weighted } \\
\text { TSE BLADE }\end{array}$ & $\begin{array}{c}\text { T1- weighted } \\
\text { GE } \\
\text { (In-opp phase) }\end{array}$ & $\begin{array}{c}\text { DWI EPI } \\
\mathrm{b}=50,400,1000 \mathrm{~s} / \mathrm{mm} 2\end{array}$ & $\begin{array}{c}\text { T1-weighted 3D } \\
\text { GE } \\
\text { VIBE (dynamic) } \\
\end{array}$ \\
\hline \multicolumn{6}{|l|}{ Parameter } \\
\hline Matrix (fr x p) & $320 \times 224$ & $320 \times 256$ & $320 \times 224$ & $128 \times 102$ & $320 \times 224$ \\
\hline $\begin{array}{l}\text { Slice thickness } \\
(\mathrm{mm})\end{array}$ & 5.0 & 7.0 & 5.0 & 5.0 & 3.0 \\
\hline Distance factor & $20 \%$ & $20 \%$ & $20 \%$ & $20 \%$ & $20 \%$ \\
\hline TR (ms) & 1400 & 2500 & 206 & 5500 & 3.92 \\
\hline $\mathrm{TE}(\mathrm{ms})$ & 93 & 89 & $\begin{array}{l}\text { TE (i) } 2.46 \\
\text { TE (o) } 6.15 \\
\end{array}$ & 75 & 1.39 \\
\hline \begin{tabular}{|l} 
Flip angle \\
(degree)
\end{tabular} & 180 & 140 & 70 & - & 9 \\
\hline Fat suppression & & SPAIR & - & SPAIR & Q-fat sat \\
\hline Reduction factor & 2 & 2 & 2 & 2 & 2 \\
\hline NEX & 1 & 1 & 1 & 4 & 1 \\
\hline Number of slices & 30 & 30 & 35 & 25 & 64 (per phase) \\
\hline FoV (mm) & $380 \times 380$ & $380 \times 380$ & $380 \times 224$ & $380 \times 296$ & 380x308 \\
\hline Plane & Coronal & Transvers & Transvers & Transvers & Transvers \\
\hline $\begin{array}{l}\text { Band width } \\
\text { (Hz/Px) }\end{array}$ & 446 & 300 & 280 & 2442 & 400 \\
\hline Breathing control & Breath hold & Navigator & Breath hold & Free//Navigatr & Multibreath hold \\
\hline $\begin{array}{l}\text { Acquisition time } \\
\text { (min:s) }\end{array}$ & $0: 42$ & $4: 32$ & $0: 40$ & $4: 24$ & 1:08 \\
\hline
\end{tabular}

\section{Statistical analysis}

Statistical analysis was performed using a commercially available software (Statistical Package for Social Sciences, version 15.0, SPSS Inc., Chicago, Illinois, USA). The results were reported as means $\pm \mathrm{SD}$. The $t$ test was used to compare the differences between mean ADC values obtained in papillary RCC and clear cell RCC groups. Also, significances of the differences between mean SI values at diffusion-weighted images with $\mathrm{b}=50 \mathrm{~s} / \mathrm{mm}^{2}$ of clear cell RCC and normal parenchyma were analyzed with $t$ test. Significances of the differences between mean SI values at diffusion-weighted images with $\mathrm{b}=1000 \mathrm{~s} /$ $\mathrm{mm}^{2}$ of papillary RCC and normal parenchyma were analyzed with paired t-test (paired samples $t$ test). Significances of the differences between mean SI values at diffusion-weighted images with $\mathrm{b}=400 \mathrm{~s} / \mathrm{mm}^{2}$ of papillary RCC and normal parenchyma; clear cell RCC and normal parenchyma were analyzed with paired t-test (paired samples $t$ test). $P$ values less than 0.05 were deemed to indicate a statistically significant difference.

\section{Results}

The mean ADC value was significantly lower in papillary $\mathrm{RCC}\left(0.991 \pm 0.143 \times 10^{-3} \mathrm{~mm}^{2} / \mathrm{s}\right)$ than in that of clear cell RCC $(1.296 \pm .0 .277 \times$ $\left.10^{-3} \mathrm{~mm}^{2} / \mathrm{s}\right)(\mathrm{p}<0.05)($ Fig 1$)$. For the papillary RCC group, there was statistically significant difference $(\mathrm{p}<0.05)$ between mean SI values of normal parenchyma $(22.8 \pm 6.3)$ and lesion $(43.4 \pm 14.8)$ at $b=1000 \mathrm{~s} / \mathrm{mm}^{2} \mathrm{DWI}$; for the clear cell RCC group, there was statistically significant difference $(\mathrm{p}<0.05)$ between mean SI values of normal parenchyma $(138.8 \pm 33)$ and lesion $(102 \pm 27.5)$ at $b=50 \mathrm{~s} / \mathrm{mm}^{2}$ DWI. For the papillary RCC group, there was not statistically significant difference $(p>0.05)$ between mean SI values of normal parenchyma $(62.5 \pm 21.8)$ and lesion $(75 \pm 28.8)$ at $b=400$ $\mathrm{s} / \mathrm{mm}^{2} \mathrm{DWI}$. For the clear cell group, there was not statistically significant difference $(p>0.05)$ between mean SI values of normal parenchyma 
(58.8 \pm 9.4) and lesion (54.1 \pm 15.4$)$ at $b=400$ $\mathrm{s} / \mathrm{mm}^{2}$ DWI.
The MRI findings of lesions are presented in Table 2. Examples of our cases is presented in Figs. 2 and 3.

Table 2. MRI findings of lesions

\begin{tabular}{|c|c|c|c|c|c|c|c|c|}
\hline & T1- weighted GE & $\begin{array}{l}\text { T2-weighted } \\
\text { HASTE }\end{array}$ & $\begin{array}{l}\text { T2- weighted } \\
\text { TSE BLADE }\end{array}$ & $\begin{array}{c}\text { DWI } \\
b=50 \mathrm{~s} / \mathrm{mm}^{2}\end{array}$ & $\begin{array}{c}\text { DWI } \\
b=400 \mathrm{~s} / \mathrm{mm}^{2}\end{array}$ & $\begin{array}{c}\text { DWI } \\
b=1000 \mathrm{~s} / \mathrm{mm}^{2}\end{array}$ & ADC & $\begin{array}{l}\text { T1-weighted 3D GE } \\
\text { VIBE(dynamic) }\end{array}$ \\
\hline 1 & Isointense & Hyperintense & Hyperintense & Isointense & Hyperintense & Hyperintense & Hypointense & Not performed \\
\hline 2 & Isointense & Hypointense & Hypointense & Isointense & Hyperintense & Hyperintense & Hypointense & Not performed \\
\hline 3 & Isointense & Hypointense & Hypointense & Isointense & Hyperintense & Hyperintense & Hypointense & Not performed \\
\hline 4 & Iso-hypointense & $\begin{array}{l}\text { Hypo- } \\
\text { hyperintense }\end{array}$ & $\begin{array}{l}\text { Hypo- } \\
\text { hyperintense }\end{array}$ & Isointense & Hyperintense & Hyperintense & Hypointense & Not performed \\
\hline 5 & Isointense & Hypointense & Hypointense & Isointense & Hyperintense & Hyperintense & Hypointense & Moderate enhancement \\
\hline 6 & Isointense & Hypointense & Hypointense & Isointense & Hyperintense & Hyperintense & Hypointense & Moderate enhancement \\
\hline 7 & Iso- hyperintense & $\begin{array}{l}\text { Hypo- } \\
\text { Hyperintense }\end{array}$ & $\begin{array}{l}\text { Hypo- } \\
\text { Hyperintense }\end{array}$ & Isointense & Hyperintense & Hyperintense & Hypointense & Not performed \\
\hline 8 & Hypointense & Hypointense & Hypointense & Isointense & Hyperintense & Hyperintense & Hypointense & Not performed \\
\hline 9 & Iso- hyperintense & Hypointense & Hypointense & Isointense & Hyperintense & Hyperintense & Hypointense & Moderate enhancement \\
\hline 10 & Iso- hyperintense & $\begin{array}{l}\text { Hypo- } \\
\text { Hyperintense }\end{array}$ & $\begin{array}{l}\text { Hypo- } \\
\text { Hyperintense }\end{array}$ & $\begin{array}{l}\text { Hypo- } \\
\text { Hyperintense }\end{array}$ & Iso- hyperintense & $\begin{array}{l}\text { Iso- } \\
\text { hyperintense }\end{array}$ & $\begin{array}{l}\text { Hypo- } \\
\text { Hyperintense }\end{array}$ & Not performed \\
\hline 11 & Iso-hypointense & $\begin{array}{l}\text { Iso- } \\
\text { hyperintense }\end{array}$ & $\begin{array}{l}\text { Iso- } \\
\text { hyperintense }\end{array}$ & $\begin{array}{l}\text { Hypo- } \\
\text { Hyperintense }\end{array}$ & Iso- hyperintense & $\begin{array}{l}\text { Iso- } \\
\text { hyperintense }\end{array}$ & $\begin{array}{l}\text { Hypo- } \\
\text { Hyperintense }\end{array}$ & Not performed \\
\hline 12 & Hypointense & $\begin{array}{l}\text { Hypo- } \\
\text { Hyperintense }\end{array}$ & $\begin{array}{l}\text { Hypo- } \\
\text { Hyperintense }\end{array}$ & $\begin{array}{l}\text { Hypo- } \\
\text { Hyperintense }\end{array}$ & Iso- hyperintense & $\begin{array}{l}\text { Iso- } \\
\text { hyperintense }\end{array}$ & $\begin{array}{l}\text { Hypo- } \\
\text { Hyperintense }\end{array}$ & Not performed \\
\hline 13 & $\begin{array}{l}\text { Hypo- } \\
\text { Hyperintense }\end{array}$ & $\begin{array}{l}\text { Iso- } \\
\text { hyperintense }\end{array}$ & $\begin{array}{l}\text { Hypo- } \\
\text { Hyperintense }\end{array}$ & $\begin{array}{l}\text { Hypo- } \\
\text { Hyperintense }\end{array}$ & Iso- hyperintense & $\begin{array}{l}\text { Iso- } \\
\text { hyperintense }\end{array}$ & $\begin{array}{l}\text { Hypo- } \\
\text { Hyperintense }\end{array}$ & Not performed \\
\hline 14 & $\begin{array}{l}\text { Hypo- } \\
\text { Hyperintense }\end{array}$ & $\begin{array}{l}\text { Iso- } \\
\text { hypointense }\end{array}$ & $\begin{array}{l}\text { Hipo- } \\
\text { Hiperintens }\end{array}$ & $\begin{array}{l}\text { Hypo- } \\
\text { Hyperintense }\end{array}$ & Iso- hyperintense & $\begin{array}{l}\text { Iso- } \\
\text { hyperintense }\end{array}$ & $\begin{array}{l}\text { Hypo- } \\
\text { Hyperintense }\end{array}$ & Not performed \\
\hline 15 & Iso-hypointense & $\begin{array}{l}\text { Iso- } \\
\text { hyperintense }\end{array}$ & $\begin{array}{l}\text { Iso- } \\
\text { hyperintense }\end{array}$ & $\begin{array}{l}\text { Hypo- } \\
\text { Hyperintense }\end{array}$ & Iso- hyperintense & $\begin{array}{l}\text { Iso- } \\
\text { hyperintense }\end{array}$ & $\begin{array}{l}\text { Hypo- } \\
\text { Hyperintense }\end{array}$ & Heterogen enhancement \\
\hline 16 & Iso-hypointense & $\begin{array}{l}\text { Iso- } \\
\text { hyperintense }\end{array}$ & $\begin{array}{l}\text { Iso- } \\
\text { hyperintense }\end{array}$ & $\begin{array}{l}\text { Hypo- } \\
\text { Hyperintense }\end{array}$ & Iso- hyperintense & $\begin{array}{l}\text { Iso- } \\
\text { hyperintense }\end{array}$ & $\begin{array}{l}\text { Hypo- } \\
\text { Hyperintense }\end{array}$ & Heterogen enhancement \\
\hline
\end{tabular}




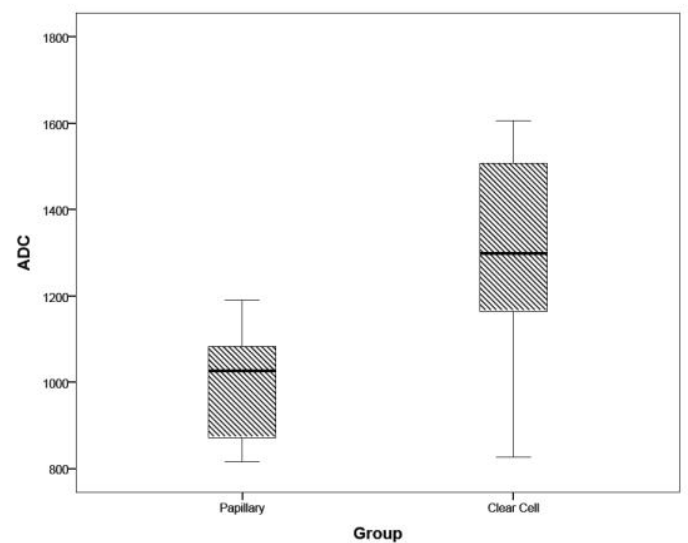

Figure 1. Graphic representation of the ADC values $\left(\mathrm{x} 10^{-3} \mathrm{~mm}^{2} / \mathrm{s}\right)$ of papillary and clear cell RCC groups.
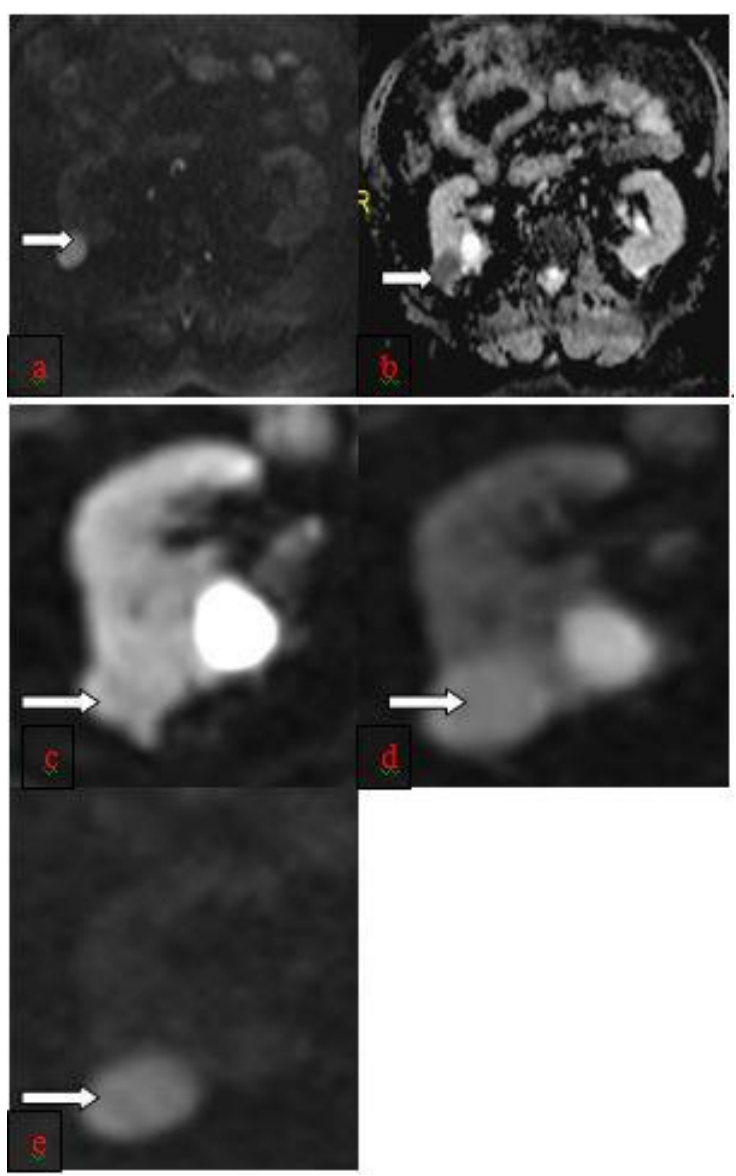

Figure 2. a-e. A 68 year-old-male with papillary RCC. Arrows show the tumor. (a) Axial DW imaging obtained with $b$ value of $1000 \mathrm{~s} / \mathrm{mm}^{2}$. Mean signal intensity value is measured 40. (b) ADC map shows that the ADC of the tumor is $0.90 \times 10^{-3} \mathrm{~mm}^{2} / \mathrm{s}$. (c) In DW images obtained with b value of $50 \mathrm{~s} / \mathrm{mm}^{2}$ the papillary RCC (showed with arrow) was hardly distinguishable from adjacent parenchyma (d) DW images obtained with b value of $400 \mathrm{~s} / \mathrm{mm}^{2}$, (e) in DW images obtained with $b$ value of $1000 \mathrm{~s} / \mathrm{mm}^{2}$, the papillary RCC has become more clearly visible by the suppression of the surrounding tissue.

\section{Discussion}

Recent studies suggested that DWI could provide comparable accuracy to contrastenhanced MRI in identifying renal lesions $(7,9)$. In our study, we found that the mean ADC value was statistically significantly lower in papillary RCC than in that of clear cell RCC. In a study conducted by Wang et al, lear cell RCCs demonstrated higher ADCs than papillary RCCs and chromophobic RCCs ; with $\mathrm{b}$ values of 0 and $800 \mathrm{~s} / \mathrm{mm}^{2}$, papillary RCCs showed lower ADCs than chromophobic RCCs, while with b values of 0 and $500 \mathrm{~s} /$ $\mathrm{mm}^{2}$, no significant difference in ADC was seen between papillary RCCs and chromophobic RCCs (8). In the study of Paudyal et al, a significant difference in ADC values between clear cell carcinoma and nonclear cell carcinoma was found (10). Yu et al. presented that the ADC value was also statistically different between clear cell RCC and non- clear cell RCC, and between different grades of clear cell RCC except grade I vs II and grade III vs IV(11). Inci et al. found statistically significant difference with ADC values and $\mathrm{b}$ factors of 500 and 1000 in types of renal carcinoma, the mean ADC value of chromophobe cell carcinoma was significantly higher than that of papillary cell carcinoma and clear cell carcinoma(12). We did not evaluate chromophobe cell carcinoma, because we had only one patient with this subtype. Taouli et al. have reported that DW imaging can be used to characterize renal lesions; however, compared with contrast enhanced MR imaging, it is less accurate . Our study focused on the efficacy of DWI, the relationship between DWI and contrast enhanced MR imaging in differentiation of subtypes of renal cell carcinoma was not evaluated. In the study of Sandrasegaran et al, there was no significant difference between the ADCs of clear cell cancers and non-clear cell cancers (13). However, they used minimum ADC per lesion whereas we used mean ADC value.

A wide range in ADCs in subtypes of renal cell carcinoma has been reported in the literature: We found mean ADC value $0.991 \pm$ $0.143 \times 10^{-3} \mathrm{~mm}^{2} / \mathrm{s}$ in papillary RCC and 1.296 $\pm .0 .277 \times 10^{-3} \mathrm{~mm}^{2} / \mathrm{s}$ in clear cell RCC, which were different in the study of Yu et al $(1.053 \pm$

Adress for correspondence: Uzm. Dr. Hale Çolakoğlu Er, Sehitkamil Devlet Hastanesi Pirsultan Mah. Çetin Emeç Caddesi Radyoloji, Gaziantep - Türkiye

e-mali: halecolakoglu83@yahoo.com

Available at www.actaoncologicaturcica.com

Copyright @Ankara Onkoloji Hastanesi 
0.380 in papillary RCC and $1.469 \pm 0.417$ in clear cell RCC ). This probably is caused by using different $b$ values. The mean ADC values in our study were similar to the mean ADC values in the study of Inci et al. $(0.90 \pm$ $0.16 \times 10^{-3} \mathrm{~mm}^{2} / \mathrm{s}$ in papillary RCC and 1.23 $\pm .0 .13 \times 10^{-3} \mathrm{~mm}^{2} / \mathrm{s}$ in clear cell RCC). Zhang et al. indicated that the ADC values measured with low $b$ values showed high standart deviations (14).

In the study of Wang et al, higher b values than $800 \mathrm{~s} / \mathrm{mm}^{2}$, such as $1000 \mathrm{~s} / \mathrm{mm}^{2}$, were not selected because according to their experience, when a b value of $1000 \mathrm{sec} / \mathrm{mm}^{2}$

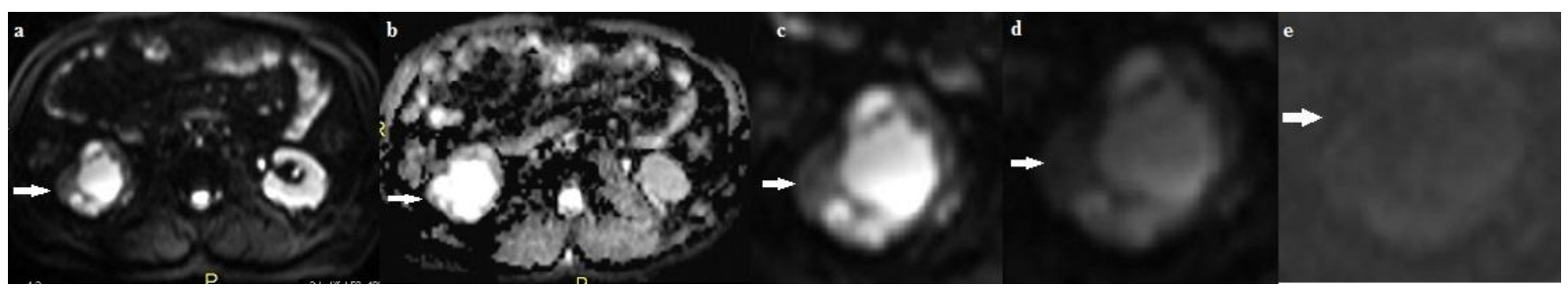

Figure 3. a-e. A 60 year-old-female with clear cell RCC. Arrows show the tumor with cystic and necrotic areas. (a) Axial DW imaging obtained with b value of $50 \mathrm{~s} / \mathrm{mm}^{2}$. Mean signal intensity value is measured 98. (b) ADC map shows that the ADC of the tumor is $1.42 \times 10^{-3} \mathrm{~mm}^{2} / \mathrm{s}$. (c) In DW images obtained with b value of $50 \mathrm{~s} / \mathrm{mm}^{2}$ the clear cell RCC (showed with arrow) was clearly visible because of shining of cystic areas(d) DW images obtained with b value of $400 \mathrm{~s} / \mathrm{mm}^{2}$ (e) in DW images obtained with b value of $1000 \mathrm{~s} / \mathrm{mm}^{2}$, the clear cell RCC was hardly distinguishable from adjacent parenchyma.

is used, the signal-to-noise ratio (SNR) of DW images decreases so significantly that part of the images cannot be evaluated. In our study, we used $b=1000 \mathrm{~s} / \mathrm{mm}^{2}$ value because it seemed more appropriate for distinguishing RCC subtypes by using ADCs and we did not experience difficulties in analyzing images due to low SNR.

Different from the other studies, we also measured mean SIs on diffusion weighted images. For the papillary RCC group, there was statistically significant difference $(\mathrm{p}<0.05)$ between mean SI value in $b=1000 \mathrm{~s} / \mathrm{mm}^{2}$ values between normal parenchyma $(22.8 \pm 6.3$ and lesion (43.4 \pm 14.8$)$. For the clear cell RCC group, there was statistically significant difference between mean SI value in $b=50$ $\mathrm{s} / \mathrm{mm}^{2}$ values between normal parenchyma(138.8 \pm 33 and lesion $(102 \pm 27.5)$ This allows us to discriminate the lesion borders easily on $b=1000 \mathrm{~s} / \mathrm{mm}^{2}$ diffusion images and on $b=50 \mathrm{~s} / \mathrm{mm}^{2}$ diffusion images, respectively for papillary RCC and clear cell RCC.

In previous studies, investigators have evaluated the value of DWI in assessing the cellularity of renal masses. In the study of Squillaci et al, the mean ADC value of renal tumors did not significantly correlate with tumor cellularity (15). Rosenkrantz et al, have reported that ADC values, obtained with $b$ values 0 and 400 and 0 and $800 \mathrm{~s} / \mathrm{mm}^{2}$, were lower among high-grade than among lowgrade ccRCC (16).

Diffusion- weighted imaging has been limited due to its artifacts associated with respiratory motion, peristaltism and cardiac pulsations. Breath-hold EPI technique (17) which we also used in our study helps DWI to become feasible to cope such artifacts seen in abdomen imaging $(18,19)$. Most of the recent studies on DWI usually performed with $1.5 \mathrm{~T}$ MRI system. In the present investigation, we used a 3-T MRI which had advantage of improved SNR compared to 1.5 T. However, comparative studies showed high correlation of the ADC values between both field strengths $(20,21)$.

Our study had some limitations. We assessed small number patients in our study. Further studies with a large number of populations are necessary to confirm our findings. Several factors such as ROI shape, partial-volume effects, MRI equipment, intraobserver variability affect the ADC measurements $(22,23)$. Possible measurement errors due to above-mentioned factors may lead to misdiagnoses and should be taken into consideration when DWI is used to discriminate the RCC subtypes.

Conflict of Interest: None 


\section{References}

1. National Cancer Institute. Surveillance, Epidemiology, and End Results Program. SEER stat fact sheets: kidney and renal pelvis cancer, 2013.

2. Nickerson ML, Jaeger E, Shi Y, Durocher JA, Mahurkar S, Zaridze D, et al. Improved identification of von Hippel-Lindau gene alterations in clear cell renal tumors. Clin Cancer Res 2008; 14:4726-34.

3. Crepel M, Jeldres C, Perrotte P, Capitanio U, Isbarn $\mathrm{H}$, Shariat SF, et al. Nephron-sparing surgery is equally effective to radical nephrectomy for T1BNOM0 renal cell carcinoma: a population-based assessment. Urology 2010; 75:271-5.

4. Holdsworth SJ, Bammer R.Magnetic resonance imaging techniques: fMRI, DWI, and PWI. Semin Neurol 2008; 28:395-406.

5. Koh DM, Collins DJ. Diffusion-weighted MRI in the body: applications and challenges in oncology. AJR Am. J. Roentgenol 2007; 188:1622-35.

6. Elmi A, Hedgire SS, Covarrubias D, Abtahi SM, Hahn PF, Harisinghani M. Apparent diffusion coefficient as a non-invasive predictor of treatment response and recurrence in locally advanced rectal cancer. Clin Radiol 2013; 68:524-531.

7. Taouli B, Thakur RK, Mannelli L, Babb JS, Kim S, Hecht EM, et al. Renal lesions: characterization with diffusion-weighted imaging versus contrast-enhanced MR imaging. Radiology 2009; 251:398-407.

8. Wang H, Cheng L, Zhang X, Wang D, Guo A, Gao Y, et al. Renal cell carcinoma: diffusion-weighted MR imaging for subtype differentiation at 3.0 T. Radiology 2010; 257:135-43.

9. Kim S, Jain M, Harris AB, Lee VS, Babb JS, Sigmund EE, et al. T1 hyperintense renal lesions: characterization with diffusion-weighted MR imaging versus contrast-enhanced MR imaging. Radiology 2009; 251: 796-807.

10. Paudyal B, Paudyal P, Tsushima $Y$, Oriuchi N, Amanuma M, Miyazaki M, et al. The role of the ADC value in the characterisation of renal carcinoma by diffusion-weighted MRI. British Journal of Radiology 2010;83:336-43.

11. $\mathrm{Yu} X$, Lin $M$, Ouyanga $H$, Zhou $C$, Zhang $H$, et al. Application of ADC measurement in characterization of renal cell carcinomas with different pathological types and grades by $3.0 \mathrm{~T}$ diffusion-weighted MRI. European Journal of Radiology 2012;81:3061-3066.

12. İnci $E$, Hocaoglu $E$, Aydin $S$, Cimilli T. Diffusion weighted magnetic resonance imaging in evaluation of primary solid and cystic renal masses using the Bosniak classification. Eur J Radiol 2012;81:815-20.

13. Sandrasegaran K., Sundaram P., Ramaswamy R. Akisik FM, Rydberg MP, Lin C, et al. Usefulness of Diffusion-Weighted Imaging in the Evaluation of Renal Masses AJR 2010; 194:438-445.

14. Zhang JL, Sigmund EE , Chandarana H, Rusinek $\mathrm{H}$, Chen Q, Vivier PH, et al . Variability of renal apparent diffusion coeffi cients: limitations of the monoexponential model for diffusion quantifi cation .Radiology 2010 ; 254: 783 - 792.

15. Squillaci E, Manenti G, Di Stefano F, Miano R, Strigari L, Simonetti G. Diffusion-weighted MR imaging in the evaluation of renal tumours. J Exp Clin Cancer Res 2004;23:39-45.
16. Rosenkrantz AB, Niver BE, Fitzgerald EF, Babb JS, Chandarana $\mathrm{H}$, Melamed J. Utility of the apparent diffusion coefficient for distinguishing clear cell renal cell carcinoma of low and high nuclear grade. American Journal of Roentgenology 2010;195:344-51.

17. Müller MF , Edelman RR . Echo planar imaging of the abdomen . Top Magn Reson Imaging 1995 ; 7 : 112 119 .

18. Matoba $\mathrm{M}$, Tonami $\mathrm{H}$, Kondou $\mathrm{T}$, Yokota $\mathrm{H}$, Higashi $\mathrm{K}$, Toga $\mathrm{H}$, et al . Lung carcinoma: diffusionweighted MR imaging-preliminary evaluation with apparent diffusion coeffi cient . Radiology 2007 ; 243: $570-577$.

19. Inan $\mathrm{N}$, Arslan A, Akansel G, Anik Y, Sarisoy HT, Ciftci $\mathrm{E}$, et al . Diffusionweighted imaging in the differential diagnosis of simple and hydatid cysts of the liver . AJR Am J Roentgenol 2007; 189: 1031-1036 .

20. Cornfeld DM, Weinreb JC. MR imaging of the prostate: $1.5 \mathrm{~T}$ versus 3T. Magn Reson Imaging Clin N Am 2007;15:433-48. 40.

21. Habermann CR, Gossrau P, Kooijman H, Graessner J, Cramer MC, Kaul MG, et al. Monitoring of gustatory stimulation of salivary glands by diffusion-weighted MR imaging: comparison of $1.5 \mathrm{~T}$ and $3 \mathrm{~T}$. AJNR Am J Neuroradiol 2007; 28:1547-51.

22. Feuerlein S, Pauls S, Juchems MS, Stuber T, Hoffmann MH, Brambs HJ, et al. Pitfalls in abdominal diffusion-weighted imaging: how predictive is restricted water diffusion for malignancy. AJR Am Roentgenol 2009;193:1070-1076.

23. Le Bihan D, Poupon C, Amadon A, Lethimonnier F. Artifacts and pitfalls in diffusion MRI. J Magn Reson Imaging. 2006;24:478-88. 